\title{
Physico-chemical parameters and primary productivity of a fish pond of Madhumara, Biratnagar
}

\author{
Purna Bahadur Chhetri and Damodar Thapa Chhetry* \\ Department of Zoology, Post Graduate Campus, T.U., Biratnagar, Nepal \\ *E-mail: thp.damodar7@gmail.com
}

\begin{abstract}
The physico-chemical parameters and primary productivity of a fish pond of Madhumara, Biratnagar was studied from October 2007 to September 2008. The maximum air and water temperature and water transparency were recorded in rainy season, whereas maximum $\mathrm{pH}$, dissolved oxygen and chloride were recorded in winter season. Free carbon dioxide and total hardness were maximum in summer season. The gross primary productivity, net primary productivity and community respiration were found maximum in winter season.
\end{abstract}

Key words: Community respiration, dissolved oxygen, free carbon dioxide, net primary productivity, total alkalinity.

\section{Introduction}

Limnology is the branch of ecology which deals with various physico-chemical and biological parameters of water bodies. A large number of literature have been published on different aspects of physico-chemical and biological parameters of fresh water body by several limnologist (Welch 1952, Mc Combie 1953, Mc Coll 1972, Rawat et al. 1995, Ferro 1976, Pradhan 1982, Lohman et al. 1988, McEachern 1994, Karn 1999, Surana 2005, Tiwari 2007).

\section{Study area}

The present study was done in the fish pond of Madhumara, Biratnagar. It is about $1.4 \mathrm{~km}$ east from the main town. It lies between $26^{\circ} 20^{\prime}$ to $26^{\circ} 53^{\prime} \mathrm{N}$ latitude and $87^{\circ} 16^{\prime}$ to $87^{\circ} 41^{\prime} \mathrm{E}$ longitude and at an elevation of $115 \mathrm{~m}$ above sea level. The total area of this pond is approximately is 5.2 ha. The human settlements, rice fields and recreation complex are found around the pond. The pond is fed by direct atmospheric precipitation and water supply from the recreation complex.

\section{Materials and Methods}

For the study of physico-chemical parameters the pond was divided in three sub-stations. From each station three samples were analyzed and their average value was calculated. The physicochemical parameters were analyzed in the field between $7 \mathrm{a}$. m. to 11 a.m. The physico-chemical parameters was analyzed as per standard methods recommended by Adoni (1985), Zobel et al.(1987) and APHA (1998). Primary productivity and community respiration was determined by light and dark bottle of modified Winkler's method.

For the statistical analysis, standard deviation and correlation coefficient were calculated by using Microsoft excel statistical function of computer software. 


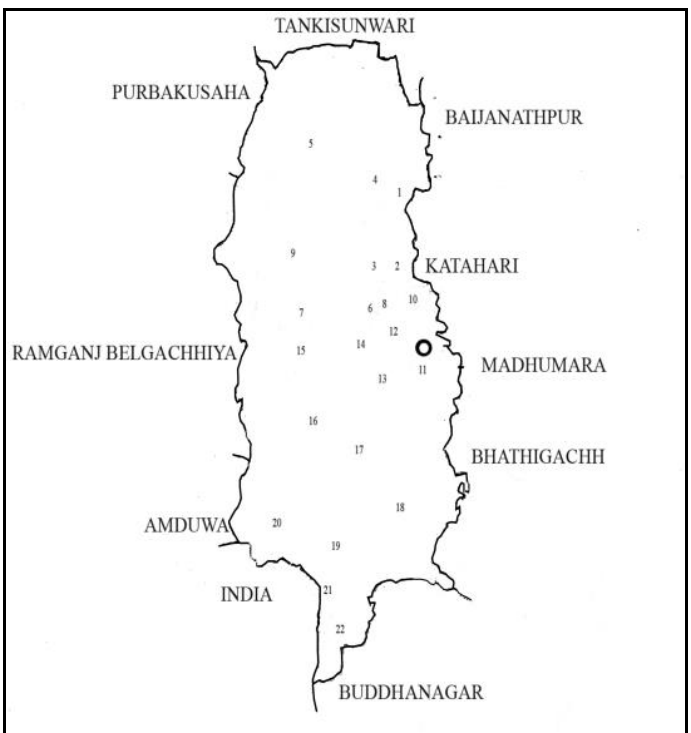

Figure 1. Map of Biratnagar Sub-Metropolitan city, showing location of study area.

\section{Results}

Mean values along with standard deviation of air temperature, physico-chemical parameters, primary productivity and community respiration of pond water are given in Table 1 . Table 2 shows the correlation coefficient (r) values, and Table 3 shows the seasonal variations of air temperature and physico-chemical parameters of pond water.

Table 1. Water colour, air temperature, physico-chemical parameters and primary productivity of pond water (mean \pm standard deviation

\begin{tabular}{lcccccccccccc}
\hline $\mathbf{P}$ & \multicolumn{10}{c}{ Months } \\
\cline { 2 - 15 } & Oct. & Nov. & Dec. & Jan. & Feb. & Mar. & Apr. & May. & Jun. & Jul. & Aug. & Sept. \\
\hline Co* & YB & $\mathrm{C}$ & $\mathrm{C}$ & $\mathrm{C}$ & $\mathrm{C}$ & $\mathrm{G}$ & $\mathrm{G}$ & $\mathrm{G}$ & $\mathrm{B}$ & $\mathrm{B}$ & $\mathrm{B}$ & YB \\
\hline $\mathrm{AT}$ & $33 \pm 0$ & $27 \pm 0$ & $23 \pm 0$ & $18 \pm 0$ & $25 \pm 0$ & $28 \pm 0$ & $30 \pm 0$ & $32 \pm 0$ & $28 \pm 0$ & $30 \pm 0$ & $32 \pm 0$ & $34 \pm 0$ \\
\multirow{2}{*}{$\mathrm{WT}$} & 31.2 & 23.6 & 20.5 & 17.7 & 23.3 & 27.1 & 28.5 & 30.1 & 27.3 & & 31.4 & 33.1 \\
& \pm 0.04 & \pm 0.24 & \pm 7.56 & \pm 0.15 & $\pm 0.16 \pm 0.14$ & \pm 0.09 & \pm 0.17 & \pm 0.31 & $29 \pm 0$ & \pm 0.47 & \pm 0.91 \\
\hline \multirow{2}{*}{$\mathrm{T}$} & 43.8 & 41.6 & 22 & 25.8 & 25.9 & 20.4 & 16.9 & 29.7 & 17.5 & 50.8 & 45 & 38.7 \\
& \pm 0.28 & \pm 4.24 & \pm 3.03 & $\pm 0.94 \pm 0.06 \pm 1.81$ & \pm 0.78 & \pm 7.84 & \pm 1.03 & \pm 1.73 & \pm 0.70 & \pm 0.25 \\
\hline \multirow{2}{*}{$\mathrm{pH}$} & 7.9 & 8.16 & 8.03 & 8 & 7.7 & 7.7 & 7.6 & 7.8 & 5.5 & 6.6 & 7.6 & 7.2 \\
& \pm 0 & \pm 0.11 & \pm 0.02 & $\pm 0.01 \pm 0.08 \pm 0.09$ & \pm 0.07 & \pm 0.16 & \pm 2.10 & \pm 0.01 & \pm 0.18 & \pm 0.02 \\
\hline \multirow{2}{*}{$\mathrm{DO}$} & 4.6 & 4.3 & 4.8 & 5.3 & 3.2 & 3.7 & 4.3 & 4.4 & 4.1 & 5.7 & 5 & 3.8 \\
& \pm 0.16 & \pm 0.22 & \pm 0.16 & $\pm 0.01 \pm 0.09 \pm 0.01$ & \pm 0.25 & \pm 0.16 & \pm 0.09 & \pm 0.09 & \pm 0.87 & \pm 0.17 \\
\hline \multirow{2}{*}{$\mathrm{FCO}$} & 15.4 & 12.6 & 17.6 & 16.8 & 24.9 & $19 \pm$ & 16.1 & 17.3 & 12.4 & 17.6 & 19 & 15.4 \\
& \pm 1.79 & \pm 1.14 & \pm 1.79 & $\pm 2.07 \pm 2.07$ & 1.04 & \pm 2.74 & \pm 4.64 & \pm 1.04 & \pm 0 & \pm 2.74 & \pm 1.79 \\
\hline \multirow{2}{*}{$\mathrm{TA}$} & $30 \pm$ & 28.33 & 33.3 & 36.6 & 31.6 & $43.3 \pm$ & $60 \pm$ & 66.6 & 63.3 & 26.6 & $38.3 \pm$ & $45 \pm 0$ \\
& 4.08 & \pm 2.36 & \pm 2.36 & $\pm 4.71 \pm 3.36$ & 2.36 & 4.08 & \pm 4.71 & \pm 2.36 & \pm 4.71 & 2.36 & 45 \\
\hline \multirow{2}{*}{$\mathrm{TH}$} & $34 \pm$ & $29.33 \pm$ & $35.3 \pm$ & $46 \pm$ & $47.3 \pm$ & $63.3 \pm$ & $60 \pm$ & $42.6 \pm$ & $41.6 \pm$ & $41.3 \pm$ & 46.6 & $36 \pm$ \\
& 1.63 & 0.94 & 2.49 & 1.63 & 20.81 & 2.49 & 1.63 & 20.29 & 2.49 & 1.89 & \pm 0.94 & 3.27 \\
\hline $\mathrm{Cl}$ & $11.3 \pm$ & $17.9 \pm$ & $22.6 \pm$ & $21.9 \pm$ & $26 \pm$ & $23.1 \pm$ & 20.8 & $18 \pm$ & $14.6 \pm$ & $16.2 \pm$ & $15 \pm$ & $13.2 \pm$ \\
\hline
\end{tabular}




\begin{tabular}{|c|c|c|c|c|c|c|c|c|c|c|c|c|}
\hline & 1.16 & 1.77 & 1.12 & 2.03 & 0.67 & 0.67 & \pm 4.07 & 4.72 & 1.77 & 0.95 & 2.31 & 0.75 \\
\hline GPP & $\begin{array}{c}4.23 \pm \\
0.00\end{array}$ & $\begin{array}{r}3.8 \pm \\
0.19\end{array}$ & $\begin{array}{r}3.6 \pm \\
0.09\end{array}$ & $\begin{array}{r}4.4 \pm \\
0.16\end{array}$ & $\begin{array}{r}2.2 \pm \\
1.19\end{array}$ & $\begin{array}{r}2.3 \pm \\
0.09\end{array}$ & $\begin{array}{r}3.3 \pm \\
0.25\end{array}$ & $\begin{array}{r}3.4 \pm \\
0.16\end{array}$ & $\begin{array}{r}3.4 \pm \\
0.09\end{array}$ & $\begin{array}{r}4.5 \pm \\
0.09\end{array}$ & $\begin{array}{c}3.4 \\
\pm 0.19\end{array}$ & \\
\hline NPP & $\begin{array}{r}0.6 \pm \\
0.17\end{array}$ & $\begin{array}{c}0.7 \\
+0.19 \\
\end{array}$ & $\begin{array}{r}0.5 \pm \\
0.10 \\
\end{array}$ & $\begin{array}{c}0.4 \pm \\
0\end{array}$ & $\begin{array}{r}0.6 \pm \\
0.16\end{array}$ & $\begin{array}{r}0.3 \pm \\
0.09 \\
\end{array}$ & $\begin{array}{r}0.5 \pm \\
0.09 \\
\end{array}$ & $\begin{array}{c}0.4 \\
\pm 0.09 \\
\end{array}$ & $\begin{array}{r}0.4 \pm \\
0.16 \\
\end{array}$ & $\begin{array}{r}0.5 \pm \\
0.19 \\
\end{array}$ & $\begin{array}{r}0.5 \pm \\
0.09\end{array}$ & $\begin{array}{c}0.4 \\
\pm 0.16 \\
\end{array}$ \\
\hline CR & $\begin{array}{r}3.5 \pm \\
0.28 \\
\end{array}$ & $\begin{array}{r}3.2 \pm \\
0.33 \\
\end{array}$ & $\begin{array}{c}3.1 \\
\pm 0.11 \\
\end{array}$ & $\begin{array}{c}4.03 \pm \\
0.16 \\
\end{array}$ & $\begin{array}{r}1.47 \\
\pm 0.20 \\
\end{array}$ & $\begin{array}{l}2 \pm \\
0.00\end{array}$ & $\begin{array}{r}2.8 \pm \\
0.28 \\
\end{array}$ & $\begin{array}{r}2.9 \pm \\
0.19 \\
\end{array}$ & $\begin{array}{c}3.09 \pm \\
0.09 \\
\end{array}$ & $\begin{array}{r}3.9 \pm \\
0.09 \\
\end{array}$ & $\begin{array}{r}2.9 \pm \\
0.25 \\
\end{array}$ & $\begin{array}{c}2.62 \pm \\
0.17 \\
\end{array}$ \\
\hline
\end{tabular}

$\mathrm{P}=$ Parameters, Co $=$ Colour, AT $=$ Air Temperature $\left({ }^{\circ} \mathrm{C}\right)$, WT $=$ Water Temperature $\left({ }^{\circ} \mathrm{C}\right), \mathrm{T}=$ Transparency $(\mathrm{cm}), \mathrm{DO}=$ Dissolved Oxygen $(\mathrm{mg} / \mathrm{l}), \mathrm{FCO}=$ Free $\mathrm{CO}_{2}(\mathrm{mg} / \mathrm{l}), \mathrm{TA}=$ Total alkalinity $(\mathrm{mg} / \mathrm{l})$, $\mathrm{TH}=$ Total hardness $(\mathrm{mg} / \mathrm{l}), \mathrm{Cl}=$ Chloride $(\mathrm{mg} / \mathrm{l}), \mathrm{GPP}=$ Gross primary production $\left(\mathrm{g} / \mathrm{m}^{2} /\right.$ day $), \mathrm{NPP}=\mathrm{Net}$ primary production $\left(\mathrm{g} / \mathrm{m}^{2} /\right.$ day $), \mathrm{CR}=$ Community respiration $\left(\mathrm{g} / \mathrm{m}^{2} /\right.$ day $), * \mathrm{YB}=$ Yellowish Brown: $\mathrm{C}=$ Clear; $\mathrm{G}=$ Greenish; $\mathrm{B}=$ Brown.

Table 2. Karl Pearson's Co-efficient correlation for air temperature, physico-chemical parameters and primary productivity of pond water.

\begin{tabular}{|c|c|c|c|c|c|c|c|c|c|c|c|}
\hline \multirow{2}{*}{$\frac{\mathbf{P}}{\mathrm{AT}}$} & AT & WT & $\mathrm{T}$ & $\mathrm{P}^{\mathrm{H}}$ & DO & $\mathrm{FCO}$ & TA & $\mathrm{TH}$ & $\mathrm{Cl}$ & GPP & NPP $\quad$ CR \\
\hline & & & & & & & & & & & \\
\hline WT & $0.954 * *$ & & & & & & & & & & \\
\hline $\mathrm{T}$ & $0.595^{*}$ & $0.598 *$ & & & & & & & & & \\
\hline $\mathrm{P}^{\mathrm{H}}$ & -0.302 & -0.386 & 0.083 & & & & & & & & \\
\hline DO & 0.274 & 0.244 & 0.432 & -0.016 & & & & & & & \\
\hline $\mathrm{FCO}$ & $-0.579 *$ & -0.501 & -0.076 & 0.319 & -0.24 & & & & & & \\
\hline TA & 0.127 & 0.209 & -0.575 & -0.387 & -0.271 & -0.256 & & & & & \\
\hline TH & -0.403 & -0.268 & -0.545 & -0.04 & 0.213 & 0.413 & 0.39 & & & & \\
\hline $\mathrm{Cl}$ & $-0.933 * *$ & $-094 * *$ & $-0.599 * *$ & 0.398 & -0.26 & $0.616^{*}$ & -0.08 & 0.494 & & & \\
\hline GPP & 0.367 & 0.331 & 0.463 & -0.036 & $0.878 * *$ & -0.522 & -0.28 & -0.51 & -0.446 & & \\
\hline NPP & 0.006 & -0.009 & 0.437 & 0.371 & 0.092 & 0.07 & -0.5 & -0.48 & -0.039 & 0.255 & \\
\hline CR & 0.388 & 0.353 & 0.392 & -0.1 & $0.893 * *$ & $-0.579 *$ & -0.18 & -0.43 & -0.456 & $0.981 * *$ & 0.076 \\
\hline
\end{tabular}

$\mathrm{P}=$ Parameters, $\mathrm{AT}=$ Air Temperature $\left({ }^{\circ} \mathrm{C}\right), \mathrm{WT}=$ Water Temperature $\left({ }^{\circ} \mathrm{C}\right), \mathrm{T}=$ Transparency $(\mathrm{cm}), \mathrm{DO}=$ Dissolved Oxygen $(\mathrm{mg} / \mathrm{l}), \mathrm{FCO}=$ Free $\mathrm{CO}_{2}(\mathrm{mg} / \mathrm{l}), \mathrm{TA}=$ Total alkalinity $(\mathrm{mg} / \mathrm{l}), \mathrm{TH}=$ Total hardness $(\mathrm{mg} / \mathrm{l}), \mathrm{Cl}=$ Chloride $(\mathrm{mg} / \mathrm{l}), \mathrm{GPP}=$ Gross primary production $\left(\mathrm{g} / \mathrm{m}^{2} /\right.$ day $), \mathrm{NPP}=$ Net primary production $\left(\mathrm{g} / \mathrm{m}^{2} /\right.$ day $), \mathrm{CR}=$ Community respiration $\left(\mathrm{g} / \mathrm{m}^{2} /\right.$ day $), * *$ Significant at $99 \%$ level of confidence $(\mathrm{P}<0.01)$, *Significant at $95 \%$ level of confidence $(\mathrm{P}<0.05)$. Values does not marked denote non-significant correlation.

Table 3. Seasonal variations in air temperature, physico-chemical parameters and primary productivity of pond water.

\begin{tabular}{lccc}
\hline Parameters & Summer & Rainy & Winter \\
\hline Air temperature $\left({ }^{0} \mathrm{C}\right)$ & 28.75 & 31 & 25.25 \\
Water temperature $\left({ }^{0} \mathrm{C}\right)$ & 27.25 & 29.73 & 23.25 \\
Transparency $(\mathrm{cm})$ & 21.68 & 38.23 & 33.40 \\
$\mathrm{pH}$ & 7.73 & 7.19 & 8.12 \\
Dissolved oxygen $(\mathrm{mg} / \mathrm{l})$ & 3.96 & 4.68 & 4.78 \\
Free $\mathrm{CO}_{2}(\mathrm{mg} / \mathrm{l})$ & 19.36 & 16.14 & 15.61 \\
Total alkalinity $(\mathrm{mg} / \mathrm{l})$ & 50.41 & 43.33 & 32.08 \\
Total hardness $(\mathrm{mg} / \mathrm{l})$ & 59.5 & 46.66 & 36.16 \\
Chloride $(\mathrm{mg} / \mathrm{l})$ & 21.57 & 14.81 & 15.93 \\
GPP $\left(\mathrm{g} / \mathrm{m}^{2} /\right.$ day $)$ & 2.856 & 3.628 & 4.034 \\
NPP $\left(\mathrm{g} / \mathrm{m}^{2} /\right.$ day $)$ & 0.487 & 0.470 & 0.556 \\
$\mathrm{CR}\left(\mathrm{g} / \mathrm{m}^{2} /\right.$ day $)$ & 2.373 & 3.158 & 3.494 \\
\hline
\end{tabular}




\section{Colour}

The colour of water was observed yellowish brown in the month of September and October then it remained clear from November to February and gradually changed to greenish till May. From June to August the colour changed to brown.

\section{Temperature}

The minimum value of air temperature was recorded $18 \pm 0^{\circ} \mathrm{C}$ in January and maximum value was $34 \pm 0^{\circ} \mathrm{C}$ in September. Seasonally, maximum air temperature was recorded in rainy season followed by summer and winter. The temperature of water fluctuated according to the atmospheric temperature. The minimum temperature was $17.7 \pm 0.15^{\circ} \mathrm{C}$ in January and maximum was $33.1 \pm 0.91^{\circ} \mathrm{C}$ in September. Seasonally, maximum water temperature was recorded in rainy season. Water temperature showed positive and significant correlation with air temperature $(\mathrm{r}=0.954,9<0.01)$.

\section{Transparency}

The minimum Secchi disc transparency was recorded $16.9 \pm 0.78 \mathrm{~cm}$ in April and maximum $50.8 \pm 1.73 \mathrm{~cm}$ in July. Seasonally, the maximum value was recorded in rainy season followed by summer and winter seasons, respectively. Transparency showed positive and significant correlation with water temperature $(\mathrm{r}=0.598, \mathrm{P}<0.05)$

$$
p H
$$

$\mathrm{P}^{\mathrm{H}}$ values of the pond water remained almost alkaline throughout the study period except June and July. The minimum $\mathrm{P}^{\mathrm{H}}$ was $5.5 \pm 2.10$ in June and maximum $8.16 \pm 0.11$ in November. The variation in $\mathrm{pH}$ within sub sites was not considerable. Seasonally, the maximum value was recorded in winter followed by summer and rainy seasons.

\section{Dissolved oxygen ( $\left.\mathrm{Do}_{2}\right)$}

The minimum value of dissolved oxygen was recorded $3.2 \pm 0.09 \mathrm{mg} / \mathrm{L}$ in February and maximum value was recorded $5.7 \pm 0.09 \mathrm{mg} / \mathrm{L}$ in the month of July. Seasonally, the maximum value was recorded in winter then followed by rainy and winter.

Free Carbon dioxide ( $\left.\mathrm{FCO}_{2}\right)$

The free carbon dioxide showed its minimum value $12.4 \pm 1.04 \mathrm{mg} / \mathrm{l}$ in June and maximum value was $24.9 \pm 2.07 \mathrm{mg} / \mathrm{l}$ in February. Free carbon dioxide values showed marked variation between the sampling stations. Maximum value was recorded in summer followed by rainy and winter seasons, respectively.

\section{Total alkalinity}

The value of total alkalinity ranged between $26.6 \pm 4.71 \mathrm{mg} / \mathrm{l}$ in July and $66.6 \pm 4.71 \mathrm{mg} / \mathrm{l}$ in May. It was minimum in the winter and maximum in the summer season.

\section{Total Hardness}

The maximum value of total hardness was recorded $63.3 \pm 2.49 \mathrm{mg} / \mathrm{l}$ in March and minimum value was recorded $29.33 \pm 0.94$ in November. 


\section{Chloride}

The minimum value of chloride was $11.3 \pm 1.16 \mathrm{mg} / \mathrm{l}$ in October and maximum $26 \pm 0.67 \mathrm{mg} / \mathrm{l}$ in February. The concentration of chloride showed marked variation between the sampling stations.

\section{Gross Primary Productivity}

The gross primary productivity value ranged between $2.2 \pm 1.19 \mathrm{~g} / \mathrm{m}^{2} /$ day to $4.5 \pm 0.09 \mathrm{~g}$ $/ \mathrm{m}^{2} /$ day. The maximum value was recorded in July and minimum in February. The gross primary productivity does not showed marked variation between the sampling stations.

\section{Net primary productivity}

The net primary productivity ranged between $0.3 \pm 0.09$ to $0.7 \pm 0.19 \mathrm{~g} / \mathrm{m}^{2} /$ day. The minimum value was recorded in March and maximum in November.

\section{Community respiration}

The community respiration value ranged between $1.47 \pm 0.20$ to $4.03 \pm 0.16 \mathrm{~g} / \mathrm{m}^{2} / \mathrm{day}$. The maximum value was recorded in January and minimum in February.

\section{Discussion}

The colour of the pond water showed marked variation between the sampling stations probably due to suspended and dissolved particles as well as due to phytoplankton and algal blooms. The brown and yellowish brown colour of water in rainy season may be due to suspended particles and dissolved solids whereas the greenish colour of water in March, April and May may be due to over growth of phytoplanktons and algal blooms.

The highest air temperature was in the month of September (Table 1). Both air and water temperature was found higher in rainy and lower in winter season. Similar observations were made by Chakraborty et al. (1959), Welch (1952) and Munawar (1970).

The higher transparency of water in the rainy season may be due to settling of suspended particles and gradual decrease in plankton growth whereas lower value of transparency in summer season may be due to presence of suspended particles and disposal of waste by the local inhabitants. Mc Combie (1953) recorded a direct relationship of transparency with suspended organisms and non living particles in the water.

$\mathrm{pH}$ value of water reflects it chemical condition. The maximum $\mathrm{P}^{\mathrm{H}}$ in winter season may be due to algal blooms and lower value in rainy season may be due to lower photosynthesis. The $\mathrm{P}^{\mathrm{H}}$ of investigated pond was found suitable for fish culture. In the present investigation $\mathrm{P}^{\mathrm{H}}$ showed insignificant negative correlation with total alkalinity but Rawat et al. (1995) reported positive correlation with total alkalinity.

The concentration of dissolved oxygen was maximum in winter and minimum in summer season. Lower value of oxygen resulted due to high temperature and retarded photosynthetic activities of planktons. Elmore (1961) stated that an increase in temperature of water results in the decrease of dissolved oxygen. The dissolved oxygen showed significant positive correlation with gross primary production and community respiration but insignificant negative correlation 
with carbon dioxide. Jindal and Kumar (1993) have reported significant negative correlation with carbon dioxide.

The minimum value of free carbon dioxide found during winter season may be due to increment of phytoplankton as they used carbon dioxide for photosynthesis. Similar observation was recorded by Gautam (1990). Higher concentration of total alkalinity recorded during summer season may be due to high rate of photosynthesis. Chakraborty et al. (1959) also recorded similar trend. The maximum value of total hardness recorded in summer season may be due to the decomposition of molluscan shell more in summer. Khan and Choudhary (1994) have opined similarly. Higher value of chloride recorded in summer season and lowest in winter season. Swarup and Singh (1979) also reported increased amount of chloride in summer season. The gross primary productivity value was maximum in July and minimum recorded in February. The maximum value may be due to maximum day length and nutrients availability from the organic matter present. Seasonally, the maximum value was recorded in winter season. The maximum value of net primary productivity was recorded in winter season probably due to excess storage of organic matter in plant tissue. The community respiration was recorded maximum in January and minimum in February. The maximum value of community respiration in winter season may be due to gaseous and heat exchange with the environment associated with metabolic breakdown of organic matter by living cells.

\section{References}

Adoni, A.D. 1985. Workbook on Limnology, Bandana Printing Service, New Delhi.

APHA.1998. Standard methods for the examination of water and waste water, $20^{\text {th }}$ Ed., Washington DC.

Chakraborty, R., D.P. Roy \& S.B. Singh. 1959. A quantitative study of the plankton and physicochemical conditions of the river Jamuna at Allahabad in 1954-55. Indian J. Fish. 6: 186203.

Elmore, H.L. \& W.F. West. 1961. Effect of water temperature on stream reaeration. IASCF 87 SA 6:59.

Ferro, W. 1976. Some limnological and biological data from Rara, a deep Himalayan lake in Nepal. Journal of the Nepal Research Resource Center 2(3): 241-261.

Gautam, A. 1990. Ecology and Pollution of Mountain Waters. Ashish Publishing House New Delhi.

Jindal, R. \& R. Kumar.1993. Limnology of a freshwater pond of Nalagarh (Himachal Pradesh India). 1. Physico-chemical complexes. In: Advances in Limnology (Singh, H.R. Ed.), pp. 107-112. Narendra Publishing House, Delhi.

Karn, D.P. 1999. Studies on physico-chemical parameters and effects on Zooplankton in Singhia river, Biratnagar. Department of Zoology, Post Graduate Campus, Tribhuvan University, Biratnagar (M.Sc. Dissertation)

Khan, M.A.G. \& S.H. Chowdhary. 1994. Physical and chemical limnology of lake Kaptai Bangaladesh. Tropical Ecology 35(1): 35-51.

Lohman, K., M.F.K. Jones., D.G. Swar., M.A. Pamperl \& B.J. Brazos. 1988. Pre and post monsoon limnological characteristics of lakes in the Pokhara and Kathmandu valleys, Nepal. Verh. Internat. Verein. Limnol. 23: 558-565. 
McColl, R.H.S. 1972. Chemistry and Trophic status of Seven New Zealand Lakes. N.Z.J. Mar. Fresh W. Res. 6: 399-447. http://dx.doi.org/10.1080/00288330.1972.9515437

McCombie, A.M. 1953. Factors Influencing the growth of Phytoplankton. J. Fish Res. Bol. Cand. 10: 253-282. http://dx.doi.org/10.1139/f53-019

McEachern, P. 1994. Limnology and the natural wetlands survey. In: Safeguarding Wetlands in Nepal (Eds. Bhandari, B., Shrestha, T.B. and McEachern, P.), pp. 89-103. IUCN, Nepal.

Munawar, M. 1970. Limnological studies of fresh water ponds of Hyderabad, India-I. The Biotop. Hydrobiol. 35: 127-162. http://dx.doi.org/10.1007/BF00143305

Pradhan, B.R. 1982. Preliminary studies of Syarpu Daha mid hill lake in Rukum District, Nepal, Proc. Nat. Sc. and Tech. Congress Kathmandu.

Rawat, M.S., C.P. Sharma \& R.C. Sharma. 1995. Morphometry and physico- chemical profile of high altitude lake Deoria Tal of Garwal Himalaya. J. Freshwater Biol. 7: 1-6.

Surana, R. 2005. Wetland ecology of Chimdi lake (Birjutal), Sunsari district, Biratnagar, Nepal. Department of zoology, P.G. campus, T.U., Biratnagar, Nepal (M. Sc. Dissertation).

Swarup, K. and S.R. Singh.1979. Limnological studies on Suraha lake (Ballia). J. Inlandfish. Soc. India. 11: 22-23.

Tiwari, R.B. 2008. Studies on physico-chemical parameters and diversity of zooplanktons of Betna Wetland, belbari, Morang. Department of zoology, P.G. campus, T.U., Biratnagar, Nepal (M.Sc. Dissertation).

Welch, P.S. 1952. Limnological Methods, $2^{\text {nd }}$. Edition. M.C. Graw Hill Book Co. New York.

Zobel, D.B., P.K. Jha, M.J. Behan \&.U.K.R. Yadav. 1987. A Practical Manual for Ecology .Ratna Book Distributors, Kathmandu. 